\title{
Kontribusi Kelentukan Terhadap Kelincahan Atlet Tenis Junior Sumatera Barat
}

\author{
Irfan Arifianto $^{1}$, Sayuti Syahara ${ }^{2}$ \\ irfan19@fik.unp.ac.id, sayutisyahara@fik.unp.ac.id
}

\begin{abstract}
Abstrak. Tujuan penelitian ini adalah untuk mengungkap kontribusi kelentukan, terhadap kelincahan dengan menggunakan metode korelasional dan pengambilan sampel dilakukan dengan cara proporsional random sampling. Tahap ini diawali dengan pemilihan club dan atlet aktif latihan beberapa tahun terakhir. Data dihimpun dari tes yang dilakukan, serta diolah dengan menggunakan korelasi sederhana dan regresi sederhana. Hasilnya menunjukkan bahwa terdapat kontribusi yang signifikan kelentukan terhadap terhadap kelincahan atlet tenis junior Sumatera Barat.
\end{abstract}

Kata kunci: Kelentukan, kelincahan

\section{PENDAHULUAN}

Olahraga tenis lapangan dimainkan menggunakan raket untuk memukul bola karet (bola tenis) dengan prinsip dasar dalam bermain tenis adalah memukul bola melewati atas net dan masuk ke dalam lapangan olahraga lawan (Jim Brown, 2007). Ide permainannya adalah mematikan bola di daerah lawan, dan berusaha untuk mempertahankan bola agar tidak mati di daerah sendiri dengan cara selalu berusaha memukul bola ke daerah lawan" (Irawadi, 2009). Pada zaman sekarang permainan tenis lapangan banyak diminati oleh berbagai kalangan. Baik itu kalangan menengah ke atas dan menengah ke bawah maupun tua muda. Sehingga olahraga tenis lapangan yang dahulunya merupakan hanya dimainkan oleh para bangsawan, telah bisa dimainkan oleh seluruh kalangan.

"Permainan tenis ini terdiri dari dua jenis pertandingan yakni pertandingan tunggal (single) dan ganda (double). Dimana pertandingan ganda terdiri dari ganda putra dan ganda putri serta ganda campuran. Salah satu petenis yang memiliki kemampuan teknik yang luar biasa yakni Roger Federer. Federer menempati peringkat pertama dunia sebanyak 16 kali” (Lloyd,2009). Di Indonesia kita juga memiliki petenis berbakat seperti Christopher Rungkat. Ia adalah juara ganda putra di kelas junior pada turnamen Grand Slam Prancis terbuka 2008 bersama Henri Kontinen asal Finlandia setelah mengalahkan pasangan Jaan-Frederik Bunken 
dan Maat Reid di final (Wikipedia, 2014). Akan tetapi, atlet di Sumatera Barat masih belum mampu untuk berprestasi ditingkat Nasional. Hal ini terbukti dengan tidak masuknya atlet Sumatera Barat ke dalam ranking 50 Nasional.

Usaha untuk mematikan bola, dan menempatkan bola ke posisi yang sulit untuk di jangkau dan masuknya bolapun dihitung sebagai angka membutuhkan kemampuan bergerak dengan penempatan perpindahan yang sangat cepat. Kemampuan yang dimaksud adalah kemampuan kelincahan. Jika diamati, kemampuan kelincahan sangat dominan sekali dalam usaha untuk mengantisipasi arah datangnya bola. Kemampuan kelincahan akan berbanding lurus dengan keberhasilan mengantisipasi arah datangnya bola.

"Pengertian dari kelincahan adalah kemampuan untuk mengubah arah dan posisi tubuh atau bagian-bagiannya secara cepat dan tepat. Pemain yang lincah adalah pemain yang bergerak tanpa kehilangan keseimbangan dan kesadaran akan posisi tubuhnya" (Ismaryati, 2008). Peranan kelincahan digunakan secara langsung untuk mengkoordinasikan gerakangerakan berganda, mempermudah berlatih teknik tinggi, gerakan dapat efisien dan efektif, mempermudah daya orientasi dan antisipasi terhadap lawan dan lingkungan bertanding, menghindari terjadinya cidera (Suharno, 1985).

Permainan tenis lapangan mempertunjukkan banyak pergerakan yang menakjubkan. Hal ini dikarenakan kemampuan kondisi fisik yang salah satunya adalah kelincahan yang dimiliki para atlet. "Jika diteliti secara cermat kemampuan kelincahan dalam permainan tenis lapangan didukung beberapa unsur kondisi fisik yang diantaranya yakni kelentukan yang berfungsi ketika merubah arah yang membuat seorang atlet bisa bergerak dengan luwes," (Arifianto, 2015)

Penelitian ini ditujukan untuk dapat menjawab beberapa pertanyaan 1) Apakah ada hubungan antara kelentukan terhadap kemampuan kelincahan atlet Tenis Junior Sumatera Barat?

\section{METODOLOGI}

Metode penelitian yang digunakan adalah metode Correlation Research. Metode ini digunakan untuk mengetahui seberapa besar hubungan kecepatan terhadap kelincahan di Sumatera Barat, selanjutnya dihitung besarnya kontribusi melalui indeks determinasi yaitu $\mathrm{r}^{2}$ x 100. Sedangkan waktu penelitian dilakukan pada bulan Januari 2015. Sampel ditetapkan 
berdasarkan proporsional random sampling sebanyak 32 orang atlet tenis junior Sumatera Barat.

Teknik pengumpulan data merupakan langkah yang paling strategis dalam penelitian, karena tujuan utama dari penelitian adalah mendapatkan data yang benar (Sugiyono, 2013). Untuk kemampuan kecepatan diukur menggunakan tes sprint 15 meter, sedangkan untuk kelincahan menggunakan tes 8 penjuru mata angin. Pengolahan dilakukan dengan menggunakan anallisis korelasi dan regresi sederhana.

\section{HASIL PENELITIAN}

\section{Hasil Pengukuran Kelentukan}

Dari Hasil pengukuran Kelentukan $\left(X_{1}\right)$ yang dilakukan terhadap 32 orang Atlet tenis Junior Sumatera Barat di Sumatera Barat. Hasil penelitian diperoleh nilai tertinggi $=23,40$ dengan kategori baik sekali, dan terendah $=11,30$ dengan kategori cukup, banyak kelas 5 , interval 6, mean 18,09 dan SD 3,28 serta distribusi frekuensi sebagaimana terlihat pada tabel berikut:

Tabel. Distribusi Frekuensi Kelentukan $\left(\mathbf{X}_{1}\right)$

\begin{tabular}{|c|c|c|c|c|}
\hline \multirow{2}{*}{ No } & \multirow{2}{*}{ Kelas Interval } & \multicolumn{2}{|c|}{ Frekuensi } & \multirow{2}{*}{ Kelas Interval } \\
\hline & & Absolut & Relative & \\
\hline 1 & $\geq 24 \mathrm{~cm}$ & 0 & $0 \%$ & Baik Sekali \\
\hline 2 & $18-23 \mathrm{~cm}$ & 18 & $56,25 \%$ & Baik \\
\hline 3 & $12-17 \mathrm{~cm}$ & 14 & $43,75 \%$ & Sedang \\
\hline 4 & $6-11 \mathrm{~cm}$ & 0 & $0 \%$ & Kurang \\
\hline 5 & $\leq 5 \mathrm{~cm}$ & 0 & $0 \%$ & Kurang Sekali \\
\hline \multicolumn{2}{|r|}{ Jumlah } & 32 & $100 \%$ & \\
\hline
\end{tabular}

Berdasarkan skor rata-rata dari tingkat kelentukan yang diperoleh sebesar 18,09 cm maka dapat disimpulkan bahwa tingkat kelentukan sampel barada pada kategori baik, dimana 20 orang dengan tingkat kelentukan di bawah rata-rata dan 12 orang dengan tingkat kelentukan di atas rata-rata yang berarti lebih banyak sampel berada pada tingkat kelentukan di bawah rata-rata. Untuk lebih jelasnya hasil perhitungan dan penjabaran distribusi frekuensi data hasil tes kelentukan dapat dilihat pada histogram sebagai berikut : 


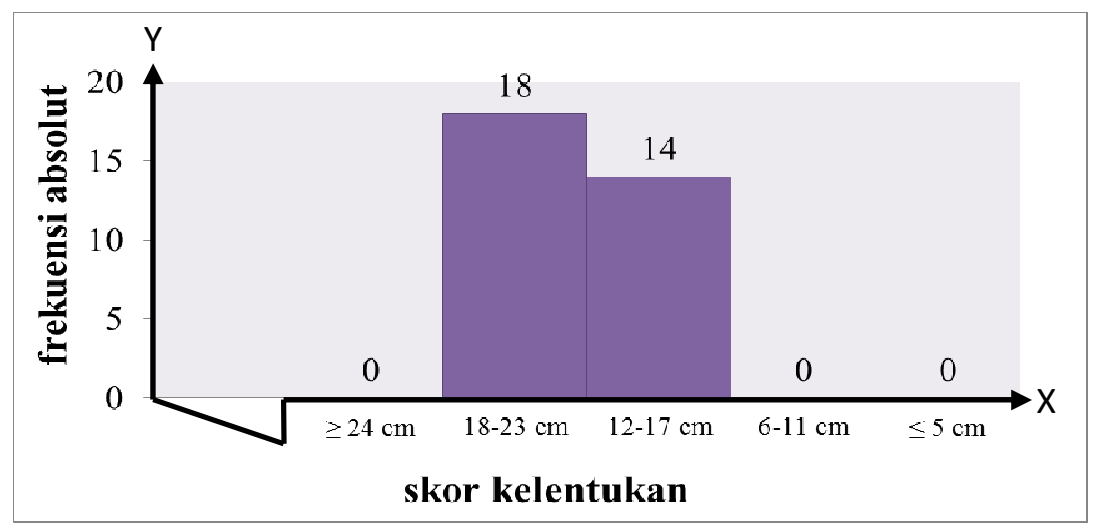

Gambar. Histogram Kelentukan

2. Hasil Pengukuran Kelincahan

Analisis variabel kelincahan, diperoleh rata-rata $=30,40$ detik dengan kategori sedang, standar deviasi $=1,09$, nilai tertinggi $=27,70$ detik dengan kategori baik sekali, dan terendah $=31,82$ detik dengan kategori sedang. Distribusi frekuensi digambarkan dalam tabel berikut.

Tabel . Distribusi Frekuensi Kelincahan (Y)

\begin{tabular}{|c|c|c|c|c|}
\hline \multirow{2}{*}{ No } & \multirow{2}{*}{ Kelas Interval } & \multicolumn{2}{|c|}{ Frekuensi } & \multirow{2}{*}{$\begin{array}{c}\text { Kelas } \\
\text { Interval }\end{array}$} \\
\hline & & Absolut & Relative & \\
\hline 1 & s.d. $-28,61$ & 2 & $6,25 \%$ & Baik Sekali \\
\hline 2 & $28,62-30,46$ & 14 & $43,75 \%$ & Baik \\
\hline 3 & $30,47-32,32$ & 16 & $50,00 \%$ & Sedang \\
\hline 4 & $32,33-34,18$ & 0 & $0 \%$ & Kurang \\
\hline 5 & $34,19-$ ke atas & 0 & $0 \%$ & Kurang Sekali \\
\hline \multicolumn{2}{|r|}{ Jumlah } & 32 & $100 \%$ & \\
\hline
\end{tabular}

Berdasarkan skor rata-rata dari kemampuan kelincahan yang diperoleh sebesar 30,40 detik maka dapat disimpulkan bahwa kemampuan kelincahan sampel barada pada kategori baik, dimana 16 orang dengan kemampuan kelincahan di bawah rata-rata dan 16 orang dengan kemampuan kelincahan di atas rata-rata. Untuk lebih jelas tentang hasil pengukuran dan penjabaran distribusi frekuensi data kelincahan dapat dilihat pada lampiran 3 halaman 88, sedangkan histogramnya pada gambar. 


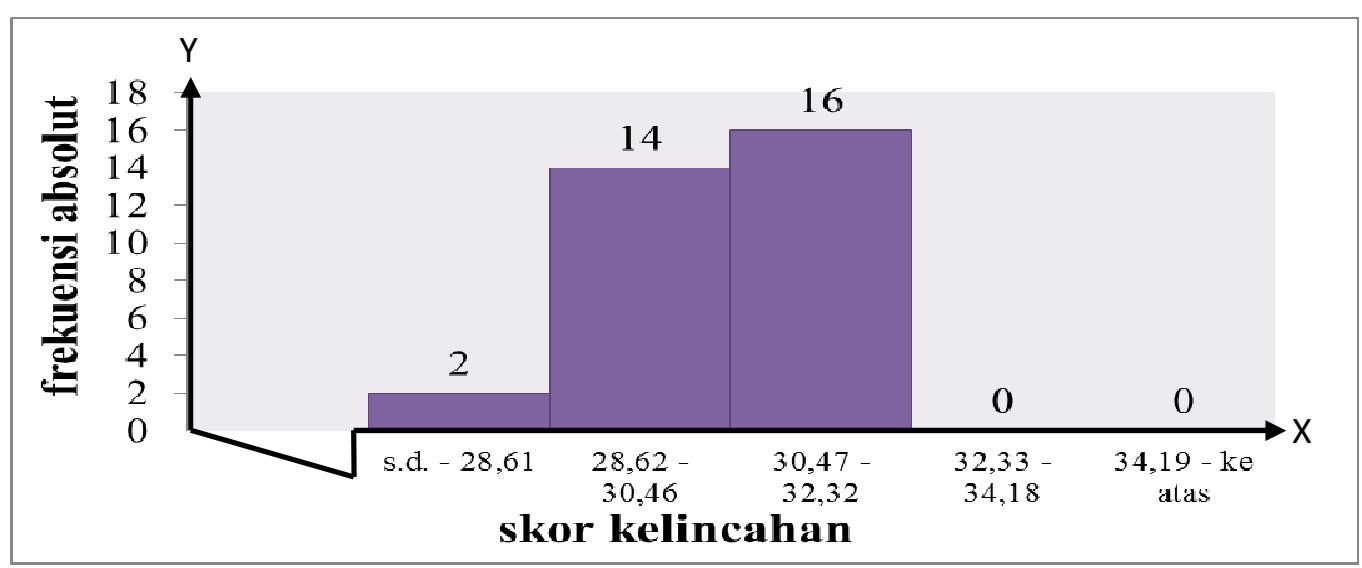

Gambar. Histogram Kelincahan

\section{PEMBAHASAN}

Berdasarkan hasil penelitian jelas bahwa kelentukan memberikan peran yang sangat baik terhadap kelincahan, karena keluasan gerak sendi akan membuat kemampuan jangkauan gerakan seseorang untuk bergerak ke segala arah semakin luas. Kelincahan juga memerlukan kombinasi antara kesimbangan (kekuatan dan kelentukan), kecepatan, kekuatan dan koordinasi (Mackenzie, 2000).

Pada saat melakukan merubah arah dalam usaha menggapai bola yang diarahkan lawan ke daerah yang sulit dijangkau membutuhkan kemampuan kelentukan yang baik. Seperti yang disampaikan oleh Sharkey (2003) menyatakan bahwa kelentukan (fleksibility) adalah jangkauan gerakan yang dapat dilakukan tangan dan kaki.

Sedangkan menurut Nurhasan (2005), kelentukan adalah kemampuan sendi untuk melakukan gerakan dalam ruang gerak sendi secara maksimal sesuai dengan kemungkinan geraknya (range of movement). Maksudnya adalah ketika melakukan usaha untuk menjangkau bola dengan usaha maksimal, maka pada saat itu ruang gerak sendi terfungsikan secara maksimal.

\section{KESIMPULAN}

Dari hasil penelitian yang telah diuraikan, dapat ditarik kesimpulan (1) terdapat kontribusi yang signifikan kelentukan terhadap kemampuan kelincahan. Ini berati bahwa apabila kemampuan kelentukan bagus, maka kemampuan kelincahan akan semakin bagus pula, begitu pula sebaliknya. Selain itu, hal ini mengisyaratkan bahwa untuk meningkatkan kemampuan kelincahan dapat dilakukan dengan meningkatkan kelentukan dari masingmasing atlet tenis Junior Smatera Barat. 


\section{Daftar Pustaka}

Arifianto, I., \& Syahara, S. (2015, August 31). Kontribusi Kelentukan, Kecepatan dan Koordinasi Mata-Kaki Terhadap Kelincahan Atlet Tenis Junior Sumatera Barat. Retrieved from osf.io/preprints/inarxiv/xd7s5

Brown, Jim. (2007). Tennis Steps to Succes (Tenis Tingkat Pemula). Penerjemah:Dian Ruslaini. Jakarta: Raja GrafindoPersada

Irawadi, Hendri. (2009). Cara mudah menguasai tenis. Malang: Wineka Media.

Ismaryati. (2008). Tes dan pengukuran olahraga. Surakrta. LPP UNS dan UNS. Press.

Lloyd. (2009). BBC sport. Diunduh tanggal 13 Januari 2015 dari http://news.bbc.co.uk /sport2/hi/tennis/8088191.stm.

Mackenzie, B. (2000) Agility [www] Available from: http://www.brianmac.co.uk/agility .htm [Accessed 17/10/2014]

Nurhasan. (2005). Aktivitas Kebugaran. Jakarta: Depdiknas

Sharkey, B.J (2003). Fitness And Health. Alih bahasa Kebugaran dan Kesehatan oleh: Eri Desmarini Nasution. Jakarta : PT. Raja Grafindo Persada

Sugiyono. (2013). Metodologi Penelitian, Bandung: AL Fabeta

Suharno. (1985). Dasar-dasar permainan bolavoli. Yogyakarta: FPOK IKIP.

Wikipedia. (2014). Christopher Rungkat - Wikipedia bahasa Indonesia. Diunduh tanggal 13 Januari 2015 dari http://id.wikipedia.org/wiki/Christopher_Rungkat. 